\title{
METODE PENYAMPAIAN DALAM PENDIDIKAN ISLAM
}

\author{
Abudzar Al Qifari \\ Fakultas Tarbiyah dan Keguruan UIN Alauddin Makassar \\ BTN Minasa Upa Blok L.9 No.4 Makassar \\ Email: abusokganteng@gmail.com
}

\begin{abstract}
The basics of disseminating Islamic education consist of religious and bio-psychological basics. Bio-psychological basic is divided into three types, namely; biological, psychological and social basics. The classical method that was carried out during the Abbasiyah dynasty led the society realized the importance of the science development and community needs. The teaching methods used at that time were oral, memorizing, and writing. Oral method included dictation, lecture, qira'ah and discussion. The methods that could be applied in schools/madrasah, namely: lecture, discussion, experimental, demonstration, assignment, sociodrama, drill method, group-work, question and answer, and project methods. Besides, the most important was the exemplary and the habituation methods.
\end{abstract}

Keywords: Teaching Method, Islamic Education

\section{PENDAHULUAN}

\section{A. Latar Belakang}

Pendidikan Islam adalah pendidikan yang berdasarkan Islam. Islam adalah agama yang dibawa oleh Nabi Muhammad saw. yang berisi seperangkat ajaran tentang kehidupan manusia, ajaran itu dirumuskan berdasarkan dan bersumber pada al-Quran dan hadis serta akal.

Agama Islam yang membawa nilai-nilai dan norma-norma kewahyuan bagi kepentingan hidup manusia di atas bumi, baru aktual dan fungsional bila diinternalisasikan ke dalam pribadi melalui proses pendidikan yang konsisten, terarah kepada tujuan.

Proses pendidikan Islam memerlukan konsep-konsep yang pada gilirannya dapat dikembangkan menjadi teori-teori yang teruji di lapangan. Bila pendidikan Islam telah menjadi ilmu yang ilmiah, dan amaliah, dapat berfungsi sebagai sarana pembudayaan manusia yang bernafaskan Islam yang lebih efektif dan efisien.

Akibat timbulnya perubahan sosial di berbagai sektor kehidupan umat manusia akhir-akhir ini, nilai-nilai pendidikan Islam seperti yang dikehendaki umat Islam, harus ikut pula bergeser sehingga merubah strategi dan taktik operasional yang menuntut perombakan model yang lebih efektif dan efisien dalam artian pedagogis, sosiologis dan kultural. $^{1}$

${ }^{1}$ H.M. Arifin,Kapita Selekta Pendidikan(Islam dan Umum)(cet. III;Jakarta;Bumi Aksara,1995), h. 3 
Pendidikan Islam yang diterapkan di sekolah-sekolah Islam itu, masih jauh dari harapan tercapainya pendidikan Islam yang berdasarkan al-Quran dan hadis, mengingat orang Islam Indonesia belum mempunyai teori Islam yang kuat tentang pengelolaan pendidikan sekolah.

Posisi lembaga pendidikan Islam saat ini sedang berada dalam arena konflik nilainilai yang membawa kepada transisi nilai kehidupan. Sekolah perlu bersikap percaya diri sendiri dalam melaksanakan tugas pokoknya yaitu membudayakan umat manusia dengan nilai-nilai ideal, yang dapat menjadi fondasi moral dan spiritual bagi tegaknya masyarakat yang adil dan makmur,sejahtera dan bahagia ruhaniah dan jasmaniah. ${ }^{2}$ Tugas sebagai seorang guru untuk menyampaikan pendidikan Islam berbagai macam metode penyampaian yang sanggup bersaing dan berlaku secara universal agar tujuan dari pendidikan Islam itu sendiri dapat tercapai dan terlaksana dengan baik.

\section{B. Rumusan Masalah}

Dari uraian singkat di atas, permasalahan pokok yang muncul kemudian adalah bagaimana metode penyampaian dalam pendidikan Islam, sehingga tujuan dari pendidikan Islam dapat tercapai. Masalah pokok tersebut di atas dirumuskan dalam sub masalahnya adalah metode penyampaian Islam, metode klasik penyampaian pendidikan Islam dan metode penyampaian pendidikan Islam di sekolah/madrasah dan luar sekolah/madrasah.

\section{PEMBAHASAN}

\section{A. Dasar-Dasar Metode Penyampaian dalam Pendidikan Islam}

Metode adalah salah satu alat atau cara untuk mencapai tujuan yang telah ditetapkan. Metode banyak tergantung pada orang yang menggunakannya: pribadi (personality)nya dalam arti keseluruhan. Oleh karena itu, orang sendiri dapat dipandang metode pula. Terlalu over metodik dalam pendidikan/pengajaran agama Islam akan mengakibatkan rigidity, inflexibility. Akan tetapi tanpa metode juga membawa akibat kekaburan wawasan pencapaian tujuan. Pendidikan Islam mempunyai metode, yang pelaksanaannya dapat disesuaikan dengan faktor-faktor pendidikan. ${ }^{3}$

Berkenaan dengan metode, ada beberapa istilah yang biasanya digunakan oleh para ahli pendidikan Islam yakni: (1) Min haj at-Tarbiyah al-Islamiyah; (2) Wasilatu atTarbiyah al-Islamiyah; (3) Kaifiyatu at-Tarbiyah al-Islamiyah; (4) Thariqatu atTarbiyah al-Islamiyah. Semua istilah tersebut sebenarnya merupakan muradif (kesetaraan) sehingga semuanya bisa digunakan. Menurut Asnely Ilyas yang penulis

\footnotetext{
${ }^{2}$ H.M. Arifin,Kapita Selekta Pendidikan(Islam dan Umum)(cet. III;Jakarta;Bumi Aksara,1995), h. 71.

${ }^{3}$ H.M. Arifin, Kapita Selekta Pendidikan(Islam dan Umum)(cet. III;Jakarta;Bumi Aksara,1995),, h. 224.
} 
kutip dari Abdul Majid; Perencanaan Pembelajaran, di antara istilah di atas yang paling populer adalah at-thariqah yang mempunyai pengertian jalan atau cara yang harus ditempuh. ${ }^{4}$

Penulis berpendapat bahwa berkenaan dengan hakikat dan belajar mengajar agama Islam, metode adalah rencana menyeluruh tentang penyajian materi ajar secara sistimatis dan berdasarkan pendekatan yang ditentukan.

Berbagai metode mengajar dapat digunakan oleh seseorang dalam kegiatan interaksi. Misalnya metode ceramah, tanya jawab, diskusi, demontrasi, dan lain-lain. Dengan menguasai metode mengajar umum, seorang guru belum dapat terjun ke muka kelas. Penguasaan metode umum ini belum cukup sebagai modal untuk mengajar dengan cepat dan tepat. Memahami metode-metode umum sesungguhnya tidaklah sulit; yang sulit ialah menerapkan metode tersebut di dalam proses pengajaran. Di dalam membuat lesson plan metode ini harus diterapkan dalam langkah-langkah pengajaran dan terintegrasi dalam langkah-langkah pengajaran tersebut. ${ }^{5}$

Dasar-dasar atau sumber umum tentang mengajar dalam pendidikan Islam dapat digolongkan dalam kategori berikut :

\section{Dasar Agama}

Kenyataan saat ini menunjukkan bahwa dalam pendidikan Islam kurang menekankan untuk bagaimana mengubah pengetahuan agama yang bersifat kognitif menjadi makna dan nilai yang mampu melekat pada pribadi-pribadi yang kokoh. Dalam pembelajaran agama Islam pendekatan doktrin-religius dan saintifikempiris sebaiknya dijalankan bersamaan. Kajian dan pendidikan agama yang hanya menekankan pada pendekatan doktrin akan cepat membosankan dan artifisal. Sedangkan pendekatan saintifik (natural science maupun behavorial science) yang tidak diberi muatan doktrin, akan menyebabkan peserta didik lupa akan sikap dan pandangan hidup yang sebenarnya. ${ }^{6}$ Penentuan macam metode atau yang dapat dipakai dalam mengajar, didapati cara-cara pendidikan yang terdapat dalam al Quran, sunah Nabi, dari sahabat dan pengikut-pengikutnya yang banyak sekali peluang untuk memilih di antaranya yang sesuai dengan mata pelajaran, perkara yang diajarkan, umur peserta didik, suasana alam sekitarnya, dan suasana pengajaran dimana ia berada. Di dalam al Quran misalnya banyak mengandung metode pendidikan, yaitu: teknik kisah (cerita), teknik tauladan yang baik, teknik pengajaran dari sejarah, teknik pembahasan akal, teknik soal jawab, teknik pemberian contoh, teknik perintah pada maruf dan melarang pada yang munkar, teknik hukuman dan balasan, teknik taubat dan hapus dosa, teknik induktif, teknik deduktif, dan lain-lain. ${ }^{7}$ Menurut penulis pendidikan dengan dasar agama senantiasa

\footnotetext{
${ }^{4}$ Abdul Majid, Perencanaan Pembelajaran Mengembangkan Standar Kompetensi Guru (Cet. V, Bandung: PT. Remaja Rosdakarya Offset, 2008), h.135.

${ }^{5}$ Ahmad Tafsir, Metodik Khusus Pendidikan Agama Islam (Cet.2, Bandung: Remaja Rosdakarya Offset,1992), h.12.

${ }^{6}$ Abdul Majid Abdul Majid, Perencanaan Pembelajaran Mengembangkan Standar Kompetensi Guru (Cet. V, Bandung: PT. Remaja Rosdakarya Offset, 2008), h. 133.

${ }^{7}$ Omar Mohammad al-Toumy al-Syaibany, Falsafah Pendidikan Islam (Cet.I, Jakarta: Bulan Bintang, 1979), h. 587.
} 
mempersiapkan peserta didik menjadi anggota masyarakat yang memahami dan mengamalkan nilai-nilai ajaran agama, yang tidak hanya dapat dilaksanakan di sekolah tetapi juga dapat dilaksanakan di rumah tangga dan masyarakat.

\section{Dasar-dasar Bio-Psikologis}

Selain dasar agama ada dasar lain yang harus dijaga dalam metode mengajar dan dalam proses pendidikan sebagai keseluruhan. Dasar ini kelihatan pada dasar bio-psikologis yang bermakna sekumpulan kekuatan dan ciri-ciri jasmaniah dan psikologis yang mempengaruhi tingkah laku pelajar pada proses belajarnya. Diantara kewajiban guru muslim adalah memahami sepenuhnya kekuatan dan ciriciri ini, dan ia memeliharanya dalam pengajarannya untuk menjamin kejayaan dalam pekerjaannya.

\section{a. Dasar Biologis,}

Dasar biologis adalah kewajiban guru untuk memelihara dalam metode teknik pengajarannya, ciri-ciri, kebutuhan-kebutuhan jasmaniah dan tahap kematangan muridnya. Guru harus memperhitungkan bahwa murid mempunyai kebutuhan biofisik yang harus dipuaskan dan dipenuhi supaya tercapai penyesuaian jasmani, psikologis dan sosial yang sehat, seperti kebutuhan kepada udara yang bersih, kebutuhan kepada gerakan dan aktivitas, dan kebutuhan kepada istirahat, tidur dan lain sebagainya. ${ }^{8}$ Penulis berpendapat bahwa guru harus dapat menempatkan diri dan menciptakan suasana yang kondusif, karena fungsi guru disekolah sebagai orang tua yang bertanggungjawab atas pertumbuhan dan perkembangan jiwa anak didik. Seorang guru harus menyadari pentingnya proses pendidikan yang dilakukan sebagaimana ungkapan Ki Hajar Dewantara; Ing ngarso sung tulodo yang berarti memberi teladan, ing madya mangun karsa yang berarti menciptakan peluang untuk berprakarsa, tut wuri handayani artinya selalu memberi dorongan dan arahan.

\section{b. Dasar Psikologis}

Dasar Psikologis adalah sejumlah kekuatan psikologis termasuk motivasi, kebutuhan, minat, sikap, keinginan, kesediaan, bakat-bakat, dan kecakapan akal (intelektual). Guru harus menjaga kesediaan-kesediaan dan keterampilan muridmurid dari segi jasmani juga harus menjaga kekuatan-kekuatan emosi, dan kecakapan intelektualnya, karena tingkah lakunya secara umum, dan kegiatan dan proses belajarnya sangat terpengaruh oleh faktor-faktor psikologis ini. ${ }^{9}$ Menurut pendapat penulis bahwa pembelajaran dapat ditingkatkan kualitasnya dengan mengembangkan kecerdasan emosi (emotional quotient), karena melalui pengembangan intelegensi saja ternyata tidak mampu menghasilkan manusia yang utuh, seperti yang diharapkan oleh pendidikan nasional. Melalui kecerdasan emosi diharapkan semua unsur yang terlibat dalam pendidikan dan pembelajaran dapat memahami diri dan lingkungannya secara tepat, memiliki rasa percaya diri, tidak iri hati, dengki, cemas, takut, murung, tidak mudah putus asa, dan tidak mudah marah. Kecerdasan emosional dapat menjadikan peserta didik: 1) jujur,disiplin dan

${ }^{8}$ Omar Mohammad al-Toumy al-Syaibany, Falsafah Pendidikan Islam (Cet.I, Jakarta: Bulan Bintang, 1979), h. 589

${ }^{9}$ Omar Mohammad al-Toumy al-Syaibany, Falsafah Pendidikan Islam (Cet.I, Jakarta: Bulan Bintang, 1979), h. 590 
tulus pada diri sendiri, membangun kekuatan dan kesadaran diri, mendengarkan suara hati, hormat dan tanggung jawab; 2) memantapkan diri, maju terus, ulet, dan membangun inspirasi secara berkesinambungan; 3) membangun watak dan kewibawaan, meningkatkan potensi, dan mengintegrasikan tujuan belajar ke dalam tujuan hidupnya; 4) memanfaatkan peluang dan menciptakan masa depan yang lebih cerah.

\section{c. Dasar sosial}

Sebagaimana metode mengajar guru Muslim terpengaruh oleh prinsip agama Islam, dan ajaran-ajarannya, dan oleh faktor-faktor masyarakat tempat tinggalnya. Dalam metode mengajar seia-sekata, dan bersesuaian dengan nilai-nilai masyarakat dan tradisi-tradisinya yang baik, dan dengan tujuan-tujuan, kebutuhan-kebutuhan, harapan-harapannya terhadap anggota-anggotanya dan tuntutan-tuntutan kehidupan yang berjaya dalam masyarakat tersebut. ${ }^{10}$ Penulis berpendapat bahwa pelaksanaan pendidikan utamanya agama Islam harus saling menunjang antara pendidikan di sekolah, rumah tangga dan lingkungan masyarakat agar tujuan dari pendidikan agama Islam yaitu membentuk manusia beriman dan bertaqwa dapat tercapai.Dengan mengetahui dasar-dasar metode sebagaimana disebutkan di atas, menurut pendapat penulis bahwa seorang guru harus mampu mengaktualisasikan yang diketahuinya, karena sesungguhnya mengajar bukanlah perbuatan yang sederhana, bila ingin menerapkan metode pembelajaran dengan cepat dan tepat.

\section{B. Metode Klasik}

Pendidikan Islam secara kelembagaan tampak dalam berbagai bentuk yang bervariasi. Di samping lembaga yang bersifat umum seperti masjid, terdapat lembagalembaga lain yang mencerminkan kekhasan orientasinya. Pada masa Abbasiyah di Bagdad, madrasah dianggap sebagai tradisi sistem pendidikan bercorak fiqh dan hadis. Dengan kekhasannya itu, pada masa khalifah Abbasiyah di Bagdad, merupakan lembaga pendidikan par excelence. Setelah perkembangan masjid dan kuttab, madrasah berkembang sangat pesat. ${ }^{11}$

Hal ini menjadi suatu gambaran bahwa, institusi pendidikan Islam mengalami perkembangan, sesuai dengan kebutuhan dan perubahan masyarakat Muslim di kala itu. Perkembangan dan kebutuhan masyarakat ditandai oleh:

1. Perkembangan ilmu. Kaum Muslimin pada masa awal membutuhkan pemahaman al Quran dasarnya, begitu juga membutuhkan keterampilan membaca dan menulis. Ibn Khaldun mencatat bahwa pada awal kedatangan Islam orang-orang Quraisy yang pandai membaca dan menulis hanya berjumlah 17 orang dan semuanya laki-laki.

2. Perkembangan kebutuhan. Pada masa awal, yang menjadi kebutuhan utama ialah mendakwahkan Islam. Karena itu, sasaranpun pada mulanya ditujukan untuk orang dewasa. Ketika keadaan semakin baik, penganut Islam semakin banyak dan kuat, terdapatlah kebutuhan untuk melakukan pendidikan untuk

\footnotetext{
${ }^{10}$ Omar Mohammad al-Toumy al-Syaibany, Falsafah Pendidikan Islam (Cet.I, Jakarta: Bulan Bintang, 1979), h. 591

${ }^{11}$ H. Maksum, Madrasah Sejarah \& Perkembangannya (Cet. 1, Jakarta: Logos Kencana Ilmu, 1999), h.52
} 
anak-anak. Selanjutnya timbul kebutuhan untuk mendidik guru, untuk pengembangan ilmu, dan untuk kebutuhan-kebutuhan masyarakat yang lebih maju, termasuk mempersiapkan pegawai.

Adapun metode pengajaran yang dipakai pada masa Dinasti Abbasiyah dapat dikelompokkan ke dalam tiga macam, yaitu lisan, hafalan dan tulisan. Metode lisan dapat berupa dikte, ceramah, qiraah dan diskusi.

1. Dikte (imla') adalah metode untuk menyampaikan pengetahuan yang dianggap baik dan aman, karena pelajar mempunyai catatan. Jika daya ingat pelajar tidak kuat, catatan dapat membantunya. Metode ini dianggap penting, karena pada masa klasik buku-buku cetakan seperti sekarang sulit sekali dimiliki. ${ }^{12}$

2. Metode ceramah disebut juga metode al-sama', sebab dalam metode ceramah, guru membacakan bukunya atau menjelaskan isi buku dengan hafalan, sedangkan murid mendengarkannya. Pada saat-saat tertentu guru berhenti dan memberi kesempatan kepada pelajar-pelajar untuk menulis dan bertanya.

3. Metode qira'ah atau membaca, biasanya digunakan untuk belajar membaca.

4. Metode diskusi merupakan metode yang khas dalam pendidikan Islam di masa ini. Ulama-ulama sering mengadakan majelis-majelis diskusi atau perdebatan.

Metode menghafal merupakan ciri umum dalam sistem pendidikan Islam di masa klasik. Metode sangat ditekankan. Untuk dapat menghafal suatu pelajaran, murid harus membaca berulang-ulang sehingga pelajaran melekat di benak mereka. Imam Hanafi mengatakan bahwa seorang murid harus membaca suatu pelajaran secara terus-menerus mengulanginya sampai menghafalnya. Akan tetapi menghafal ini dapat bersifat pasif jika murid hanya sekedar menghafal tanpa diikuti pemahaman, kemampuan mengabstraksi, atau mengkontekstualisasi, sehingga ilmu tidak berkembang. ${ }^{13}$

Adapun metode tulisan dianggap sebagai motode yang paling penting dalam pembelajaran pada ,masa klasik. Metode tulisan adalah pengkopian karya-karya ulama. Dalam pengkopian buku-buku terjadi proses intelektualisasi sehingga tingkat penguasaan ilmu seseorang semakin meningkat, dan akhirnya menimbulkan sistem ta'liqah terhadap karya-karya ulama. ${ }^{14}$

Menurut penulis semua metode yang dilakukan pada masa klasik adalah baik dan penting karena metode yang digunakan pada masa itu sesuai dengan perkembangan ilmu dan kebutuhan masyarakat yang ada. Namun menurut penulis metode tulisan jauh lebih baik dibanding metode yang lain mengingat dengan tulisan seseorang dapat menunjukkan intelektualisasinya dan tulisan adalah merupakan gabungan dari semua metode yang ada.

\footnotetext{
${ }^{12}$ Hanun Asrohah, Sejarah Pendidikan Islam (cet.1, Jakarta: Logos, 1999), h.77

${ }^{13}$ Hanun Asrohah, Sejarah Pendidikan Islam (cet.1, Jakarta: Logos, 1999), h. 78.

${ }^{14}$ Hanun Asrohah, Sejarah Pendidikan Islam (cet.1, Jakarta: Logos, 1999), h. 79.
} 


\section{Metode di Sekolah dan Madrasah}

Menurut Zakiah Daradjat, metode yang dapat digunakan dalam pengajaran yaitu :

\section{Metode Ceramah}

Metode ceramah murid duduk, melihat dan mendengarkan serta percaya bahwa yang diceramahkan guru itu adalah benar, murid mengutip ikhtisar ceramah semampu murid itu sendiri dan menghafalnya tanpa ada penyelidikan lebih lanjut oleh guru yang bersangkutan. ${ }^{15}$ Metode ceramah merupakan cara menyamapaikan materi ilmu pengetahuan dan agama kepada anak didik dilakukan secara lisan. Yang perlu diperhatikan, hendaknya ceramah mudah diterima, isisnya mudah dipahami serta mampu menstimulasi pendengar (anak didik) untuk melakukan hal-hal yang baik dan benar dari isi ceramah yang disampaikan. ${ }^{16}$

Menurut E. Mulyasa, hal-hal yang perlu dipersiapkan guru dalam menggunakan metode ceramah adalah sebagai berikut:

a. Rumuskan tujuan instruksional khusus, mengembangkan pokok-pokok materi belajar-mengajar, dan mengkajinya apakah hal tersebut tepat diceramahkan.

b. Apabila akan divariasikan dengan metode lain, perlu dipikirkan apa yang akan disampaikan melalui ceramah dan apa yang akan disampaikan dengan metode lainnya.

c. Siapkan alat peraga atau media pelajaran secara matang, alat peraga atau media apa yang akan digunakan, bagaimana menggunakannya dan kapan akan digunakan. Demikian halnya kalau akan menggunakan alat pengeras suara.

d. Perlu dibuat garis besar bahan yang akan diceramahkan, minimal berupa catatan kecil yang akan dijadikan pegangan guru pada waktu berceramah. ${ }^{17}$

Dalam proses pembelajaran di sekolah, metode ceramah bertujuan untuk:

a. Menciptakan landasan pemikiran peserta didik melalui produk ceramah yaitu bahan tulisan peserta didik sehingga peserta didik dapat belajar melalui bahan tertulis hasil ceramah.

b. Menyajikan garis-garis besar isi pelajaran dan permasalahan yang terdapat dalam isi pelajaran.

c. Merangsang peserta didik u ntuk belajar mandiri dan menumbuhkan rasa ingin tahu melalui pemerkayaan belajar.

d. Memperkenalkan hal-hal baru dan memberikan penjelasan secara gamblang.

${ }^{15}$ Zakiah Daradjat, dkk. Metodik Khusus Pengajaran Agama Islam (Cet.1, Jakarta: Bumi Aksara, 1995), h. 289.

${ }^{16}$ Abdul Majid Abdul Majid, Perencanaan Pembelajaran Mengembangkan Standar Kompetensi Guru (Cet. V, Bandung: PT. Remaja Rosdakarya Offset, 2008), h. 137.

${ }^{17}$ E. Mulyasa, Menjadi Guru Profesional Menciptakan pembelajaran Kreatif dan Menyenangkan, (Cet.VIII, Bandung: PT. Remaja Rosdakarya, 2009), h.114. 
e. Sebagai langkah awal untuk metode yang lain dalam upaya menjelaskan prosedur yang harus ditempuh peserta didik. ${ }^{18}$

Menurut pendapat penulis bahwa metode ceramah adalah metode yang selalu digunakan oleh pendidik dalam menyampaikan gambaran pembelajaran secara logis, fasih, jelas dan mempunyai bobot sehingga peserta didik yang menjadi sasaran bicara (ceramah) tersebut cepat memahami, mengerti, dan menerima apa yang disampaikan atau yang diceramahkan. Kelebihan metode ceramah bahwa guru atau pendidik dapat menguasai arah kelas, dan guru dapat menarik minat serta menangkap perhatian peserta didik walaupun jumlahnya banyak.

Di samping itu, peserta didik yang kurang perhatian mudah diketahui sehingga mudah diberi rangsangan. Adapun kekurangan metode ini adalah guru kurang dapat mengetahui sampai dimana peserta didik telah memahami materi/bahan yang diceramahkan.

\section{Metode Diskusi}

Metode diskusi merupakan salah satu cara mendidik yang berupaya memecahkan masalah yang dihadapi, baik dua orang atau lebih yang masing-masing mengajukan argumentasinya untuk memperkuat pendapatnya. Untuk mendapatkan hal yang disepakati, tentunya masing-masing menghilangkan perasaan subjektivitas dan emosionalitas yang akan mengurangi bobot pikir dan pertimbangan akal yang semestinya. ${ }^{19}$

Metode ini biasanya erat kaitannya dengan metode lainnya, misalnya metode ceramah, karyawisata dan lain-lain karena metode diskusi ini adalah bagian yang terpenting dalam memecahkan sesuatu masalah (Problem Solving). Dalam dunia pendidikan metode diskusi ini mendapat perhatian karena dengan diskusi akan merangsang murid-murid berpikir atau mengeluarkan pendapat sendiri. ${ }^{20}$

Menurut pendapat penulis, kebaikan metode diskusi adalah adanya pertanyaanpertanyaan problematis yang muncul kemudian yang dengan pertanyaan itu dapat diarahkan untuk memperoleh pemecahan masalah. Dengan demikian peserta didik terbiasa bersifat demokratis, sabar, kritis dan sebagainya dengan berbagai permasalahan yang ada.

Macam-Macam diskusi :

a. Diskusi informal, terdiri dari satu diskusi yang pesertanya terdiri dari murid-murid yang jumlahnya sedikit. Peraturan-peraturannya agak longgar.

\footnotetext{
${ }^{18}$ Abdul Majid Abdul Majid, Perencanaan Pembelajaran Mengembangkan Standar Kompetensi Guru (Cet. V, Bandung: PT. Remaja Rosdakarya Offset, 2008),h. 138

${ }^{19}$ Abdul Majid Abdul Majid, Perencanaan Pembelajaran Mengembangkan Standar Kompetensi Guru (Cet. V, Bandung: PT. Remaja Rosdakarya Offset, 2008), h. 141

${ }^{20}$ Zakiah Daradjat, dkk. Metodik Khusus Pengajaran Agama Islam (Cet.1, Jakarta: Bumi Aksara, 1995), h. 292.
} 
Dalam diskusi informal ini hanya seorang yang menjadi pimpinan, tidak perlu ada pembantu-pembantu, yang lain hanya sebagai anggota diskusi.

b. Diskusi formal, diskusi ini berlangsung dalam suatu diskusi yang serba diatur dari pimpinan sampai dengan anggota kelompok. Diskusi dipimpin oleh seorang guru atau seorang murid yang dianggap cakap.

c. Diskusi panel, diskusi ini dapat diikuti oleh banyak murid sebagai peserta, yang dibagi menjadi peserta aktif dan peserta tidak aktif. Peserta aktif yaitu langsung mengadakan diskusi, sedangkan peserta tidak aktif adalah sebagai pendengar.

d. Diskusi simposium, dalam simposium masalah-masalah yang akan dibicarakan diantarkan oleh seorang atau lebih pembicara dan disebut pemrasaran. Pemrasaran boleh berpendapat berbeda-beda terhadap suatu masalah, sedangkan peserta boleh mengeluarkan pendapat menanggapi yang telah dikemukakan oleh pemrasaran. ${ }^{21}$

Menurut penulis, diskusi pada dasarnya ialah tukar menukar informasi, pendapat dan pengalaman untuk mendapat pengertian bersama yang lebih jelas dan lebih teliti tentang sesuatu dengan tujuan melatih peserta didik mengembangkan keterampilan bertanya, berkomunikasi, mengembangkan kemampuan berpikir sendiri dan menemukan pendapat.

\section{Metode Eksperimen}

Metode ini biasanya dilakukan dalam suatu pelajaran tertentu seperti ilmu alam, ilmu kimia, dan sejenisnya, biasanya terhadap ilmu-ilmu alam yang didalam penelitiannya menggunakan metode yang sifatnya objektif, baik dilakukan di dalam/ di luar kelas maupun dalam suatu laboratorium.22

Penulis berpendapat bahwa eksperimen merupakan situasi pemecahan masalah yang di dalamnya berlangsung pengujian suatu hipotesis, dan terdapat variabel-variabel yang dikontrol secara ketat. Hal yang diteliti dalam suatu eksperimen adalah pengaruh variabel tertentu terhadap variabel yang lain.

Hal-hal yang harus dipersiapkan guru dalam menggunakan metode eksperimen menurut E. Mulyasa adalah sebagai berikut:

a. Tetapkan tujuan eksperimen.

b. Persiapkan alat bantu dan atau bahan yang diperlukan.

c. Persiapkan tempat eksperimen.

d. Pertimbangkan jumlah peserta didik sesuai dengan alat-alat yang tersedia.

${ }^{21}$ Zakiah Daradjat, dkk. Metodik Khusus Pengajaran Agama Islam (Cet.1, Jakarta: Bumi Aksara, 1995), h. 293-294.

${ }^{22}$ Zakiah Daradjat, dkk. Metodik Khusus Pengajaran Agama Islam (Cet.1, Jakarta: Bumi Aksara, 1995), h.295. 
e. Perhatikan keamanan dan kesehatan agar dapat memperkecil atau menghindarkan resiko yang merugikan atau berbahaya.

f. Perhatikan disiplin atau tata tertib, terutama dalam menjaga peralatan dan bahan yang akan digunakan.

g. Berikan penjelasan tentang apa yang harus diperhatikan dan tahapan-tahapan yang mesti dilakukan peserta didik, temasuk yang dilarang dan yang membahayakan. ${ }^{23}$

\section{Metode Demonstrasi}

Metode Demonstrasi adalah metode mengajar yang menggunakan peragaan untuk untuk memperjelas suatu pengertian atau untuk memperlihatkan bagaimana melakukan sesuatu kepada anak didik. Dengan metode demonstrasi guru atau murid memperlihatkan pada seluruh anggota kelas sesuatu proses, misalnya bagaimana cara shalat yang sesuai dengan ajaran/contoh Rasulullah saw. ${ }^{24}$

Menurut penulis, metode ini sangat cocok digunakan oleh para pendidik dalam mengajarkan ajaran-ajaran agama kepada peserta didik. Salah satu hadis Nabi yang berkenaan dengan metode demonstrasi adalah tentang cara pelaksanaan shalat yang benar yang dilakukan oleh Nabi saw, lalu memerintahkan umatnya mengikuti atau mencontoh apa yang dipraktekkan oleh beliau. Dengan metode ini, dalam pengajaran agama guru mempraktekkan atau memberi contoh cara pelaksanaan ibadah dan kemudian peserta didik mengikutinya.

\section{Metode Pemberian Tugas}

Metode Pemberian Tugas adalah suatu cara dalam proses belajar-mengajar bilamana guru memberi tugas tertentu dan murid mengerjakannya, kemudian tugas tersebut dipertanggungjawabkan kepada guru. Dengan cara demikian diharapakan agar murid belajar secara bebas tapi bertanggung jawab dan murid-murid akan berpengalaman mengetahui berbagai kesulitan kemudian berusaha untuk ikut mengatasi kesulitankesulitan itu. ${ }^{25}$

Metode pemberian tugas ini biasa juga disebut metode resitasi. Metode ini dimaksudkan untuk memberikan atau pekerjaan kepada peserta didik baik dikerjakan di sekolah maupun di rumah, dan selanjutnya peserta didik mempertanggung jawabkan kepada guru apa yang telah mereka kerjakan. ${ }^{26}$

\footnotetext{
${ }^{23}$ E. Mulyasa, Menjadi Guru Profesional Menciptakan pembelajaran Kreatif dan Menyenangkan, (Cet.VIII, Bandung: PT. Remaja Rosdakarya, 2009), h. 110

${ }^{24}$ Zakiah Daradjat, dkk. Metodik Khusus Pengajaran Agama Islam (Cet.1, Jakarta: Bumi Aksara, 1995), h. 296.

${ }^{25}$ Zakiah Daradjat, dkk. Metodik Khusus Pengajaran Agama Islam (Cet.1, Jakarta: Bumi Aksara, 1995), h. 298.

${ }^{26}$ Mappanganro, Pemilikan Kompetensi Guru (Cet.I, Makassar: Alauddin Press, 2010), h. 32.
} 


\section{Metode Sosiodrama}

Metode sosiodrama adalah semacam drama atau sandiwara, akan tetapi tidak disiapkan naskahnya lebih dahulu. Tidak pula diadakan pembagian tugas yang harus mengalami latihan terlebih dahulu, tapi dilaksanakan seperti sandiwara di panggung. ${ }^{27}$

Menurut Mappanganro, metode sosiodrama adalah bentuk pembelajaran dengan mendemonstrasikan cara tingkah laku dalam hubungan social. Sosiodrama dimaksudkan mendramatisasikan suatu peristiwa yang telah mendapat petunjuk-petunjuk guru kepada peserta didik dengan tingkah laku dan kata-katanya sendiri. ${ }^{28}$

\section{Metode Drill (Latihan)}

Penggunaan istilah "Latihan" sering disamakan artinya dengan istilah "Ulangan". Padahal maksudnya berbeda. Latihan bermaksud agar pengetahuan dan kecakapan tertentu dapat menjadi milik peserta didik dan dikuasai sepenuhnya, sedangkan ulangan hanyalah untuk sekedar mengukur sejauh mana dia telah menyerap pengajaran tersebut. ${ }^{29}$

\section{Metode Kerja Kelompok}

Apabila guru dalam menghadapi peserta didik di kelas merasa perlu membagi-bagi anak didik dalam kelompok-kelompok untuk memecahkan suatu masalah atau untuk menyerahkan suatu pekerjaan yang perlu dikerjakan bersama-sama, maka cara mengajar tersebut dapat dinamakan Metode Kerja Kelompok. ${ }^{30}$

\section{Metode Tanya Jawab}

Metode tanya jawab adalah salah satu teknik mengajar yang dapat membantu kekurangan-kekurangan yang terdapat pada metode ceramah. Ini disebabkan karena guru dapat mengerti dan dapat mengungkapkan apa yang telah diceramahkan.

Metode Tanya jawab merupakan cara menyajikan bahan ajar dalam bentuk pertanyaan-pertanyaan yang memerlukan jawaban untuk mencapai tujuan. Pertanyaanpertanyaan bisa muncul dari guru, bisa juga dari peserta didik, demikian pula halnya jawaban yang muncul bisa dari guru maupun dari peserta didik. Pertanyaan dapat digunakan untuk merangsang aktivitas dan kreativitas berpikir peserta didik. Karena itu mereka harus didorong untuk mencari dan menemukan jawaban yang tepat dan memuaskan. ${ }^{31}$

\footnotetext{
${ }^{27}$ Mappanganro, Pemilikan Kompetensi Guru (Cet.I, Makassar: Alauddin Press, 2010),h.301.

${ }^{28}$ Zakiah Daradjat, dkk. Metodik Khusus Pengajaran Agama Islam (Cet.1, Jakarta: Bumi Aksara, 1995), h. 34.

${ }^{29}$ Zakiah Daradjat, dkk. Metodik Khusus Pengajaran Agama Islam (Cet.1, Jakarta: Bumi Aksara, 1995), h. 302.

${ }^{30}$ Zakiah Daradjat, dkk. Metodik Khusus Pengajaran Agama Islam (Cet.1, Jakarta: Bumi Aksara, 1995) h. 305.

${ }^{31}$ E. Mulyasa, Menjadi Guru Profesional Menciptakan pembelajaran Kreatif dan Menyenangkan, (Cet.VIII, Bandung: PT. Remaja Rosdakarya, 2009), h 115-116.
} 


\section{Metode Proyek}

Metode ini disebut juga dengan tehnik pengajaran unit. Anak didik disuguhi bermacam-macam masalah dan anak didik bersama-sama menghadapi masalah tersebut dengan mengikuti langkah-langkah tertentu secara ilmiah, logis dan sistematis. Cara demikian adalah tehnik yang modern, karena murid tidak dapat begitu saja menghadapi persoalan tanpa pemikiran-pemikiran ilmiah. Tujuan metode ini adalah untuk melatih anak didik agar berpikir secara ilmiah, logis dan sistematis. ${ }^{32}$

11. Metode teladan,

Murid-murid cenderung meneladani pendidiknya; ini diakui oleh semua ahli pendidikan, baik dari Barat maupun dari Timur. Dasarnya ialah karena secara psikologis anak memang senang meniru; tidak saja yang baik, yang jelekpun ditirunya. Sifat anak didik itu diakui dalam Islam. Umat meneladani Nabi; Nabi meneladani al Quran. Aisyah pernah berkata bahwa akhlak Rasul Allah itu adalah al-Quran.

Metode pendidikan Islam yang berpusat pada keteladanan, adalah yang memberikan teladan itu adalah guru, kepala sekolah, dan semua aparat sekolah. Teladan untuk guru-guru (dan ain-lain) ialah Rasulullah. Guru tidak boleh mengambil tokoh yang diteladani selain Rasul Allah saw. ${ }^{33}$

Menurut penulis, adanya teladan yang baik akan menumbuhkan hasrat bagi orang lain untuk meniru atau mengikutinya. Dan dengan adanya contoh ucapan, perbuatan dan contoh tingkah lakuyang baik dalam hal apapun, adalah merupakan suatu amaliyah yang penting dan berkesan baik bagi pendidikan peserta didik, maupun dalam kehidupan dan pergaulan manusia sehari-hari.

\section{Metode Pembiasaan}

Pembiasaan sebenarnya berintikan pengalaman. Apa yang dibiasakan? Ya, yang dibiasakan itu adalah sesuatu yang diamalkan. Inti pembiasaan ialah pengulangan. Jika guru masuk kelas mengucapkan salam, itu telah dapat diartikan sebagai usaha membiasakan. Dalam pembinaan sikap, metode pembiasaan sebenarnya cukup efektif. Lihatlah pembiasaan yang dilakukan oleh Rasulullah; perhatikanlah orang-orang tua kita mendidik anaknya. Anak-anak yang dibiasakan bangun pagi, akan bangun pagi sebagai suatu kebiasaan. ${ }^{34}$

Dasar pendidikan nasional adalah Pancasila, dan UUD 1945 menjadi referensi secara tidak langsung mengharuskan kita untuk menyelenggarakan proses kependidikan nasional yang konsisten dan secara integralistik menuju ke arah pencapaian tujuan akhir, yaitu terbentuknya manusia Indonesia seutuhnya yang berkualitas unggul yang

${ }^{32}$ Zakiah Daradjat, dkk. Metodik Khusus Pengajaran Agama Islam (Cet.1, Jakarta: Bumi Aksara, 1995),h. 310

${ }^{33}$ Ahmad Tafsir, Ilmu Pendidikan Dalam Persfektif Islam (cet. 8, Bandung: Pt Remaja Rosdakarya Offset), h. 143.

${ }^{34}$ Ahmad Tafsir, Ilmu Pendidikan Dalam Persfektif Islam (cet. 8, Bandung: Pt Remaja Rosdakarya Offset) h. 144 
berkembang dan bertumbuh di atas pola kehidupan yang keseimbangan antara lahiriah dan batiniah, antara jasmaniah dan rohaniah atau antara kehidupan mental dan spiritual dan fisik material. Dalam bahasa Islam, membentuk insan kamil yang secara homeostatik dapat mengembangkan dirinya dalam pola kehidupan yang hasanah fiddunya dan hasanah fil akhirat terhindar dari siksaan api neraka secara simultan tidak terpisah-pisah antara kedua unsurnya. ${ }^{35}$

Penulis berpendapat bahwa mengajar bukan suatu pekerjaan (tugas) yang mudah. Keberhasilan suatu proses pengajaran banyak ditentukan oleh strategi dan metode mengajar yang digunakan. Allah swt yang member tugas rasul untuk mengajar manusia, tidak dilepas begitu saja melaksanakan tugas mengajarnya, tetapi dapat dipastikan Allah swt memberi bimbingan dan petunjuk tentang strategi dan metode yang digunakan dalm menjalankan tugas-tugasnya.

Jalan menuju ke tujuan itu, tidak lain adalah melalui proses pendidikan yang berorientasi kepada tiga arah yaitu hubungan anak didik dengan Tuhannya, dengan masyarakatnya dan dengan alam sekitarnya.

\section{Metode Luar Sekolah}

Lingkungan sosial dan keluarga perlu diciptakan sedemikian rupa sehingga kondusif terhadap program pendidikan agama disekolah; sebaliknya pendidikan agama di sekolah harus akrab dengan lingkungannya. ${ }^{36}$

Fungsi sekolah erat hubungannya dengan kebutuhan masyarakat. Sekolah sejak mulanya didirikan oleh masyarakat untuk kepantingan masyarakat demi kelanjutan hidup, perkembangan dan kebahagiaan masyarakat. Tiap pendidik yang mencampuri persekolahan akan mempunyai pandangan masing-masing apa yang harus diajarkan agar anak-anak yang dididikakan menjadi manusia yang berguna dalam masyarakatnya. ${ }^{37}$

Herbert Spencer (1860) berpendapat bahwa yang paling perlu diajarkan di luar sekolah adalah hal-hal yang berkenaan dengan:

1. Self-preservation, usaha menjaga kelangsungan hidup individu, misalnya menjaga kesehatan, soal makanan, melindungi diri terhadap pengaruh alam, bahaya, kejahatan, dan sebagainya.

2. Securing the necessities of life, usaha mencari nafkah, untuk menutupi kebutuhan hidup, mempelajari keterampilan untuk melakukan pekerjaan tertentu, dan sebagainya.

3. Rearing of family, memelihara keluarga, mendidik anak.

4. Maintaining proper social and political relationship, memelihara hubungan sosial dan politik yang baik.

${ }^{35}$ H.M. Arifin,Kapita Selekta Pendidikan(Islam dan Umum)(cet. III;Jakarta;Bumi Aksara,1995),

${ }^{36}$ Ibid, h. 91.

${ }^{37}$ S.Nasution, Pengembangan Kurikulum (cet.IV, Bandung: PT. Citra Aditya Bakti, 1991), h.54. 
5. Enjoying leisure time, menikmati waktu senggang. ${ }^{38}$

\section{KESIMPULAN}

Dengan melihat tulisan diatas maka disimpulkan sebagai berikut:

1. Dasar-dasar penyampaian pendidikan Islam terdiri atas dasar agama, dan dasar bio-psikologis yang terbagi lagi kepada tiga macam yaitu dasar biologis, dasar psikologis dan dasar sosial.

2. Metode klasik yang pernah dilakukan pada masa Dinasti Abbasiyah menyebabkan terjadinya perkembangan pengetahuan dan kebutuhan masyarakat akan perkembangan ilmu dan perkembangan kebutuhan. Metode pengajaran yang digunakan pada masa ini adalah lisan, hafalan dan tulisan. Metode lisan dapat berupa dikte, ceramah, qiraah dan diskusi.

3. Metode-metode yang dapat diterapkan dalam lingkungan sekolah/madrasah , yaitu : metode ceramah, metode diskusi, metode eksperimen, metode demonstrasi, metode pemberian tugas, metode sosiodrama, metode drill, metode kerja kelompok, metode tanya jawab dan metode proyek. Selain itu yang paling penting adalah metode keteladanan dan metode pembiasaan.

\section{DAFTAR PUSTAKA}

Arifin, M, H. Kapita Selekta Pendidikan(Islam dan Umum), cet. III, Bumi Aksara, Jakarta: 1995

,Ilmu Pendidikan Dalam Persfektif Islam, cet. VIII, Pt Remaja Rosdakarya Offset: Bandung, 2008

Asrohah, Hanun. Sejarah Pendidikan Islam, cet.I, Logos,Jakarta : 1999

B, Chaeruddin. Metodologi Pengajaran Agama Islam Luar Sekolah, Cet. I, Lanarka Publisher, Yogyakarta: 2009

Daradjat,Zakiyah, dkk. Metodik Khusus Pengajaran Agama Islam, Cet. I, Bumi Aksara, Jakarta: 1995

Maksum, H. Madrasah Sejarah \& Perkembangannya, Cet. I, Logos Kencana Ilmu, Jakarta: 1999

Majid, Abdul. Perencanaan Pembelajaran Mengembangkan Standar Kompetensi Guru, Cet. V, PT. Remaja Rosdakarya, Bandung: 2008

${ }^{38}$ S.Nasution, Pengembangan Kurikulum (cet.IV, Bandung: PT. Citra Aditya Bakti, 1991), h. 55. 
Mappanganro, Pemilikan Kompetensi Guru, Cet. I, Alauddin Press, Makassar: 2010

Mulyasa, E. Menjadi Guru Profesional Menciptakan Pembelajaran Kreatif dan Menyenangkan, Cet. VIII, PT. Remaja Rosdakarya, Bandung: 2009

Nasution, S. Pengembangan Kurikulum, cet.IV, PT. Citra Aditya Bakti, Bandung: 1991

Rohani, Ahmad, HM, dan H. Abu Ahmadi. Pengelolaan Pengajaran, cet. I, PT. Rineka Cipta, Jakarta: 1991

Tafsir,Ahmad. Metodik Khusus Pendidikan Agama Islam, cet.II, Remaja Rosdakarya Offset, Bandung: 1992

al-Toumy al-Syaibany,Omar Mohammad. Falsafah Pendidikan Islam, Cet.I, Bulan Bintang: 1979 